\title{
TUFA DEPOSITS IN THE KARST OF MONTES CLAROS, MINAS GERAIS, BRAZIL
}

\author{
LEHNJAK NA KRAŠKEM OBMOČJU MESTA MONTES CLAROS, \\ MINAS GERAIS, BRAZILIJA
}

\author{
Luiz Eduardo Panisset TRAVASSOS ${ }^{1 *} \&$ Rachel Inêz Castro de OLIVEIRA ${ }^{2}$
}

UDC 552.545:551.44(815.1)

\section{INTRODUCTION}

The continental area of Brazil is known as 8.5 million $\mathrm{km}^{2}$ large and about 5 to $7 \%$ consist of carbonate karst terrains, a territory developed on ancient geological structures, except for the Tertiary Sedimentary Basins of Pantanal, the Amazon Basin and parts of the littoral area. On relating this information to karst areas, one can identify important cratonic areas, ancient folding belts and sedimentary basins (Schobbenhaus \& Brito Neves 2003; Travassos \& Kohler 2009). The karst features were developed in Proterozoic carbonate and dolomite rocks and the main units are located in the São Francisco Craton in the region of the States of Minas Gerais, Goiás and Bahia.

Minas Gerais stands out in the national scenery due to the amount of carbonate and karst features in its territory. Around 3 to $5 \%\left(17,600\right.$ to $\left.29,419 \mathrm{~km}^{2}\right)$ of the country's total of carbonate karst area are located in this State (Karman 1994; Piló 1997, 1998, 1999; Travassos \& Kohler 2009; Timo 2015).

Due to the considerable amount of karst and speleological provinces in the State, Minas Gerais is proving itself to be an important ground for Karstological and Speleological studies and their various humanistic subfields (Travassos et al. 2007; Andreychouk et al. 2010; Travassos et al. 2011; Antonino \& Travassos 2012; Timo et al. 2013; Travassos 2012; Travassos 2015) to physical ones (Travassos 2010; Guimarães \& Travassos 2011; Knez et al. 2011; Timo et al. 2012; Borges et al. 2013; Rodrigues \& Travassos 2013 ).

Since 2010, an effort is being made by the Chair of Karstology of the Graduate Program in Geography at the Pontifical Catholic University of Minas Gerais (in the city of Belo Horizonte, Brazil) to emphasize the importance of karst systems. Actions have been taken in both information and education, as it can be verified in the works of Lobo and Travassos (2012), Pôssas et al. (2012), Travassos et al. (2012), Diniz et al. (2013), Lobo and Travassos (2013), Evangelista and Travassos (2014), Travassos et al. (2015), etc.

This context supports the content of this paper, which intends to identify examples of tufa dams in the Municipality of Montes Claros, Minas Gerais, Brazil, for the first time. The main objective is to make a primary register so that other scientists can help local researchers go deeper in the information regarding these sites. The option for producing this specific register is

\footnotetext{
${ }^{1}$ Luiz Eduardo Panisset Travassos*, Professor at the Graduate Program in Geography, PUC Minas, Brazil, e-mail: luizepanisset@gmail.com

${ }^{2}$ Rachel Inêz Castro de Oliveira, Teacher at the Montes Claros State University, Doctorate Student at the Graduate Program in Geography, PUC Minas, Brazil, e-mail: rachelinez18@gmail.com

${ }^{*}$ Corresponding Author
}

Received/Prejeto: 15.12.2015 
justified by the fact that the works of Pentecost (1995) and Ford and Pedley (1996), among others, register around 300 sites around the world, but mention that many tufa deposits in South America exist only in Argentina, in Peru and in the Brazilian state of Bahia (Branner 1911).

Active or inactive tufa in Brazil were also found in the Serra da Bodoquena, in the State of Mato Grosso do Sul (Boggiani \& Coimbra 1994, 1995; Boggiani et al. 1998, 1999, 2002; Sallun Filho et al. 2009a, b; Boggiani et al. 2011), in the Serra das Araras region, in the Mato Grosso State (Corrêa 2006; Corrêa et al. 2011), in the Paraíba and Ceará States (Duarte \& Vasconcelos 1980a, b), in northeastern Brazil, and in the north of the State of Bahia (Auler \& Smart 2001; Wang et al. 2004), and in the Serra do André Lopes, in the south of São Paulo State (Almeida et al. 2011; Sallun Filho et al. 2012). However, no descriptions of tufas in the State of Minas Gerais were made up to the moment this paper was finished.

\section{STUDY AREA AND ITS GEOLOGICAL SETTINGS}

The Vieira River Basin is fully located in the Municipality of Montes Claros, Minas Gerais, and it drains a superficial area of approximately $578 \mathrm{~km}^{2}$. It is located in the São Francisco Depression, which has depositional plains and plan surfaces. Amidst these eroded surfaces one can see the result of differential erosion over the carbonate rocks of the Bambuí Group, Lagoa do Jacaré Formation. The tufa deposits are located within the limits of the Betânia Farm (entrance point $16^{\circ} 47^{\prime} 18,89^{\prime \prime}$ 'S $43^{\circ} 55^{\prime} 13,62^{\prime \prime} \mathrm{W}$ ), approximately $8 \mathrm{~km}$ southwest of the city of Montes Claros (Fig. 1).

Geologically speaking, the Vieira River Basin is located in the South portion of the São Francisco Craton (Fig. 2) with altitudes ranging from 450 to $950 \mathrm{~m}$. This

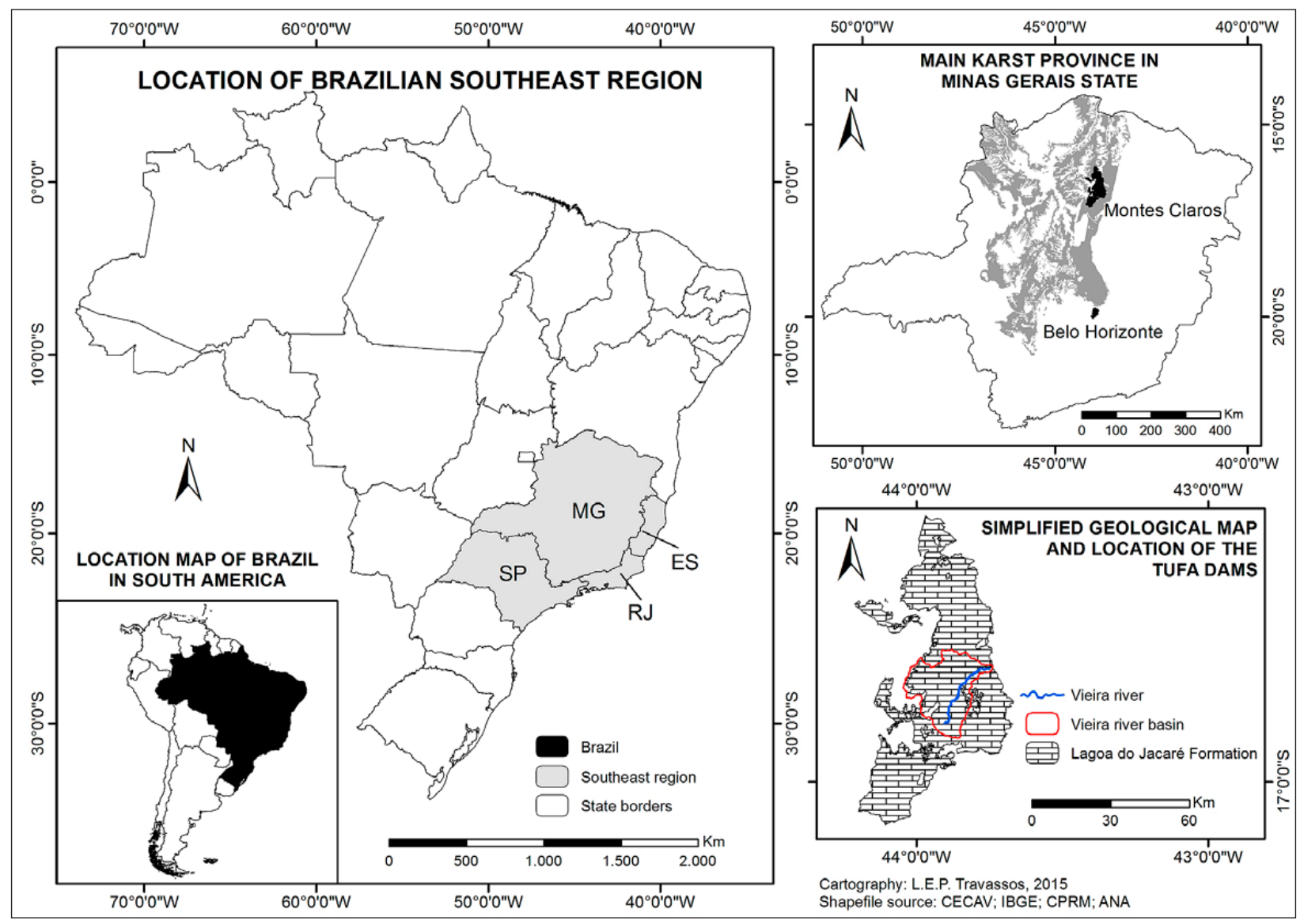

Fig. 1: Location map of Montes Claros in the State of Minas Gerais, Brazil. 


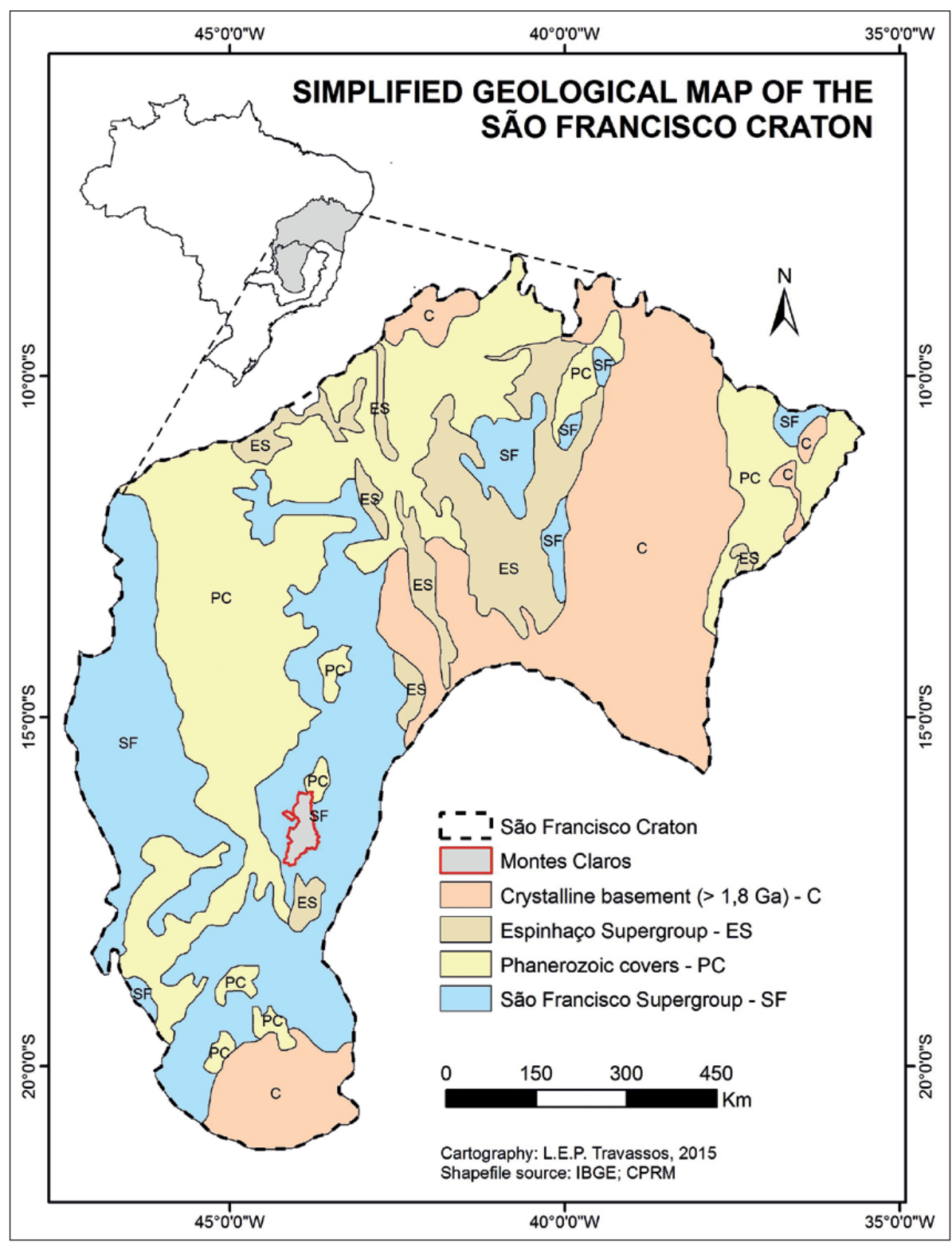

Fig. 2: A simplified geological map of the São Francisco Craton shows the position of the Municipality of Montes Claros (Modified from Alkmim et al. 1993; Alkimim et al. 1996; Alkmim \& Martins-Neto 2001).

cratonic area spreads throughout almost the whole São Francisco River Basin and is covered by sediments of various ages, from the Proterozoic to the Phanerozoic, as Alkmim and Martins-Neto (2001) mentioned it.

Almeida (1981) defined the southern portion of this Craton as being one of the areas of the South American Plataform that were individualized due to the orogenetic processes of the Brasiliano Event. According to Baptista (2004), Coelho (2007) and Chaves et al. (2011), who summarized the regional geologic evolution, many tectonic events took place within the limits of the São Francisco River Basin in its long geological history. One of the first events was a distensile one, responsible for breaking up the paleo continent of Rodínia. Then, the process of rift formation led to the development of such features in both sides of the paleo continent.

The clastic marine and glaciomarine sedimentation of the Macaúbas Group occurred in the Neoproterozoic, around $850 \mathrm{Ma}$ and 750 (?) $\mathrm{Ma}$, and the pelito-carbonatic sedimentation of the Bambuí Group (mostly important for this paper) also took place in the Neoproterozoic, between $720 \mathrm{Ma}$ and 620(?) Ma, in a shallow epicontinental sea. After such events, the basins evolved to folded belts due to the Brasiliano Orogenesis. Valadão (1998) states that, by the end of the Proterozoic and the beginning of the Phanerozoic, the Brasiliano Event (450-700 Ma) took place, and its deformational processes carried out the litho-structural reorganization of the Brazilian Atlantic Shield. 
The São Francisco Craton is limited by the Brasília Fold Belt in the west and by the Araçuaí Fold Beld in the east. In the southern portion, one can notice some individualized structural compartments (Alkimin et al. 1996) where the study area is located. The sedimentary units that are younger than $1,8 \mathrm{Ga}$ are located over the basement rocks of the Craton which are granites and migmatites (Alkimin \& Martins-Neto 2001). Covering the basement, one can identify the Proterozoic sedimentary units of the Espinhaço Supergroup and the São Francisco Group. In the last one, all the depositional sequences from the Upper Proterozoic are located, such as the ones from the Macaúbas Group and the Bambuí Group.

The study of the geology of the São Francisco river basin started in 1817 when Baron von Eschwege named "Ubergangsgebirge" - the carbonatic and pelitic sediments that outcrop in the basin - as "Transitional Forms", as mention by Eschwege (1833) cited by Baptista (2004). From the point of view of geology, the Bambuí Group is now well known, as it is confirmed by the works of Barbosa (1965), Almeida (1967), Oliveira (1967), Carvalho and Pflug (1968), Braun (1968), Moutinho da Costa and Angeira (1970), Costa et al. (1970), Scholl (1972), Pflug and Renger (1973), Almeida (1977), among others. Dardenne (1978) wrote both a synthesis and a complete revision of the Bambuí Group stratigraphy and the most recent works on this geological unit can be seen in Alkmim and Martins-Neto (2001), Martins Neto and Alkmim (2001) and Iglesias and Uhlein (2009).
The Bambuí Group is devided into six Formations: Carrancas, Sete Lagoas, Serra de Santa Helena, Lagoa do Jacaré, Serra da Saudade and Três Marias. The area in which the tufa deposits are located were developed in carbonates from the Lagoa do Jacaré Formation. The karst, as well as many units from the Bambuí Group, can be covered by alluvium, colluvium and eluvium deposits, and are sometimes bared, sometimes exposed. According to the Brazilian Geological Survey (2012), the Lagoa do Jacaré Formation is composed by rythmic metasiltites (in the base) and calcilutites and calcarenites on the top. The Vieira River flows over such units and the carbonates are dark gray, compact, and well fractured. In some portions along the river basin, one can identify the Serra da Saudade Formation (siltstones and argillites), which sometimes covers the Lagoa do Jacaré Formation. It is also possible to identify the Cenozoic covers that were mentioned by Iglesias and Uhlein (2009), such as alluvium, colluvium and eluvium.

The climate of that region is influenced by the circulation of three main air masses that favors the annual precipitation to range from 700 to $1200 \mathrm{~mm}$ and the average temperatures range from $12{ }^{\circ} \mathrm{C}$ to $35^{\circ} \mathrm{C}$. All these elements, together with geology and soil characteristics, allow the development of the Brazilian Savannahs (Cerrado) with phytophysiognomies, such as the Dry Forests connected to the karst, as it is mentioned in Rodrigues and Travassos (2013).

\section{GENERAL CONSIDERATIONS ABOUT THE TUFA DEPOSITS AND TRAVERTINES}

Pedley (1990) mentions many authors since 1970s and states that tufas are common occurrences from the Quaternary in the northwestern Europe and the Mediterranean regions. He also mentions other authors who studied tufa deposits in lacustrine settings, barrage systems and waterfalls. In all these studies, the expression tufa is used to describe all cool water deposits of highly porous or "spongy" freshwater carbonate that are also rich in leaves and woody tissues. The term is equivalent to $\mathrm{Ka}$ lktuff (in the German literature), and Travertino (in the Italian literature), also used to describe hydrothermal deposits. Although some debates can be found in the academic literature, Pedley (1990) also affirms that travertine, a common alternative term, is generally applied to well-lithified, older calcareous tufa deposits where diagenetic carbonate precipitation added considerable later calcite spar to the fabric.
The word tufa derives from tophus, used by Pliny and extensively used in Roman times to describe crumbly whitish deposits (either calcareous tufa or volcanic tuff). Scientific development and more studies on karst areas made the term tufa, defining pyroclastic materials, to be a substitute for the well-established term "volcanic tuff". Consequently, one can agree that tufa is the product of $\mathrm{CaCO}_{3}$ precipitation under a cool water (near ambient temperature) regime and typically contains the remains of micro and macrophytes invertebrates and bacteria. In contrast, they used the term "travertine" for hard, crystalline deposits that lack macrophytes or invertebrates, formed mainly from hydrothermal waters. Over the past 20 years, the study of tufas raised in importance from minor curiosities to a major new research frontier (Ford \& Pedley 1996; Pentecost 2005; Capezzuoli et al. 2014). 
The carbonate deposition in rivers tends to be localized around spots of spring emergence or associated with calcium-rich river systems (Pentecost 2005). The deposits from Montes Claros, Minas Gerais, Brazil, the theme of this paper, are located relatively far from the source and, thus, should be considered to have its processes connected to a calcium-rich hydrography. The deposits, mainly cascades and dams, can be classified as Capezzuoli et al. (2014) proposed: as the types of tufas formed in an "intermediate environment".

If an author chooses to use travertine instead of tufa, Pentecost (1995) explains that they consist of a major group of freshwater carbonates distributed all over of the world. They can be described as meteogene travertines, whose carbon dioxide originated in the epigenic and soil atmospheres, and thermogene travertines, which are formed predominantly from thermal activity involving oxidation, decarbonation and other deep outgassing processes in tectonically active regions. If one were to classify the tufas or travertines from Montes Claros, those are clearly the ones which are called meteogene; however, it would be more correct to call those deposits tufas, not travertines. It is important to mention that Boggiani et al. (1999) state that the degree of hardness alone is not sufficient to differentiate tufas from travertines. The main criteria have to do with the presence of traces of macrophytes and animals, characteristics that are restrict to tufas.

Pentecost (2005) and Jones and Renaut (2010) sustain that tufas and travertines form in most of the climatic zones. According to Jones and Renaut (2010), the precipitation of tufa and travertine are usually associated to humid climatic phases when increased recharge enhances spring flow. However, the relationship between carbonate precipitation and climate is complex and varies with latitude. In temperate regions, for example, increased rainfall may lead to stronger spring discharge and simultaneously produces waters that are more diluted and undersaturated regarding $\mathrm{CaCO}_{3}$ when they emerge at the surface. In contrast, increased aridity may lead to a decrease in spring discharge and water volumes, while higher evaporation and warmer waters might favour carbonate precipitation. In dry climates, there may be no surface discharge during the periods of aridity; so, tufa and travertine precipitation will only form during wetter periods. Local and regional conditions, including tectonic ones, which largely control hydrogeology, determine the relationship between tufa/travertine formation and climate. Good water supply and warm temperatures generally favour the forming of spring carbonates (Viles \& Pentecost 2007).

Ford and Pedley (1996) state that the traditional theory focused on tufa as wholly physic-chemical precipitates that deposit close to resurgent points, riffles and waterfalls, where waters enriched with $\mathrm{CaCO}_{3}$ rapidly de-gass and primarily lose $\mathrm{CO}_{2}$. The processes are also associated with the cooling of the waters away from source resulting in the precipitation. Pentecost (1995) points out that active tufa precipitation is severely limited by low temperatures as this severely restricts soil respiration and limestone dissolution. Thus, regimes with higher rainfall and temperatures should encourage tufa formation. There is some general support for the idea that the Late Quaternary Atlantic climatic optimum seems to be associated with a peak in tufa precipitation. Adolphe et al. (1989) and Pedley (1992, 1994) cited by Ford and Pedley (1996) defend that currently tufas are seen as a product of both physic-chemical and biogenic precipitation associated with biofilm colonization. There is usually close association among biofilms and organic nutrients often released from decaying vegetation.

\section{TUFA DEPOSITS IN BRAZIL}

As it was mentioned before, active or inactive tufas in Brazil were found in the States of Bahia, Ceará, Mato Grosso, Mato Grosso do Sul, Paraíba and São Paulo (Duarte \& Vasconcelos 1980a, b; Boggiani \& Coimbra 1994; Boggiani \& Coimbra 1995; Boggiani et al. 1998; Boggiani et al. 1999; Auler \& Smart 2001; Boggiani et al. 2002; Wang et al. 2004; Corrêa 2006; Sallun Filho et al. 2009a, b; Boggiani et al. 2011; Corrêa et al. 2011; Almeida et al. 2011; Sallun Filho et al. 2012). However, no de- scriptions of tufas in Minas Gerais were made up to the moment this paper was finished (Fig. 3).

Chronologically, such scientific findings started with Duarte and Vasconcelos (1980a, b) who described tufas with well-preserved flora fossils in the States of Ceará (CE) and Paraíba (PB), respectively. In the 1990s, Boggiani and Coimbra $(1994,1995)$ described tufas in Mato Grosso do Sul State (MS), which presents favorable conditions to its deposition, such as a significant amount 
of recharge and discharge waters. The tufas from the Serra da Bodoquena (MS), were described by Boggiani et al. (1998) and Boggiani et al. (1999), who identified innumerous ancient and modern deposits along the rivers of the region. Auler and Smart (2001) were responsible for studying the fossil travertine and subaqueous speleothems in presently dry caves. Data analysis suggest periods of enhanced ground-water recharge during the
Quaternary Period in the semiarid northeastern Brazil. The tufas in the Serra da Bodoquena (MS) were again recorded by Boggiani et al. (2002) and Wang et al. (2004) calls the attention once more to the climatic changes in northeastern Brazil.

In Mato Grosso State, specifically in the Araras Ridge (Serra das Araras, located between the towns of Cuiabá and Cáceres), Corrêa (2006) and Corrêa et al.

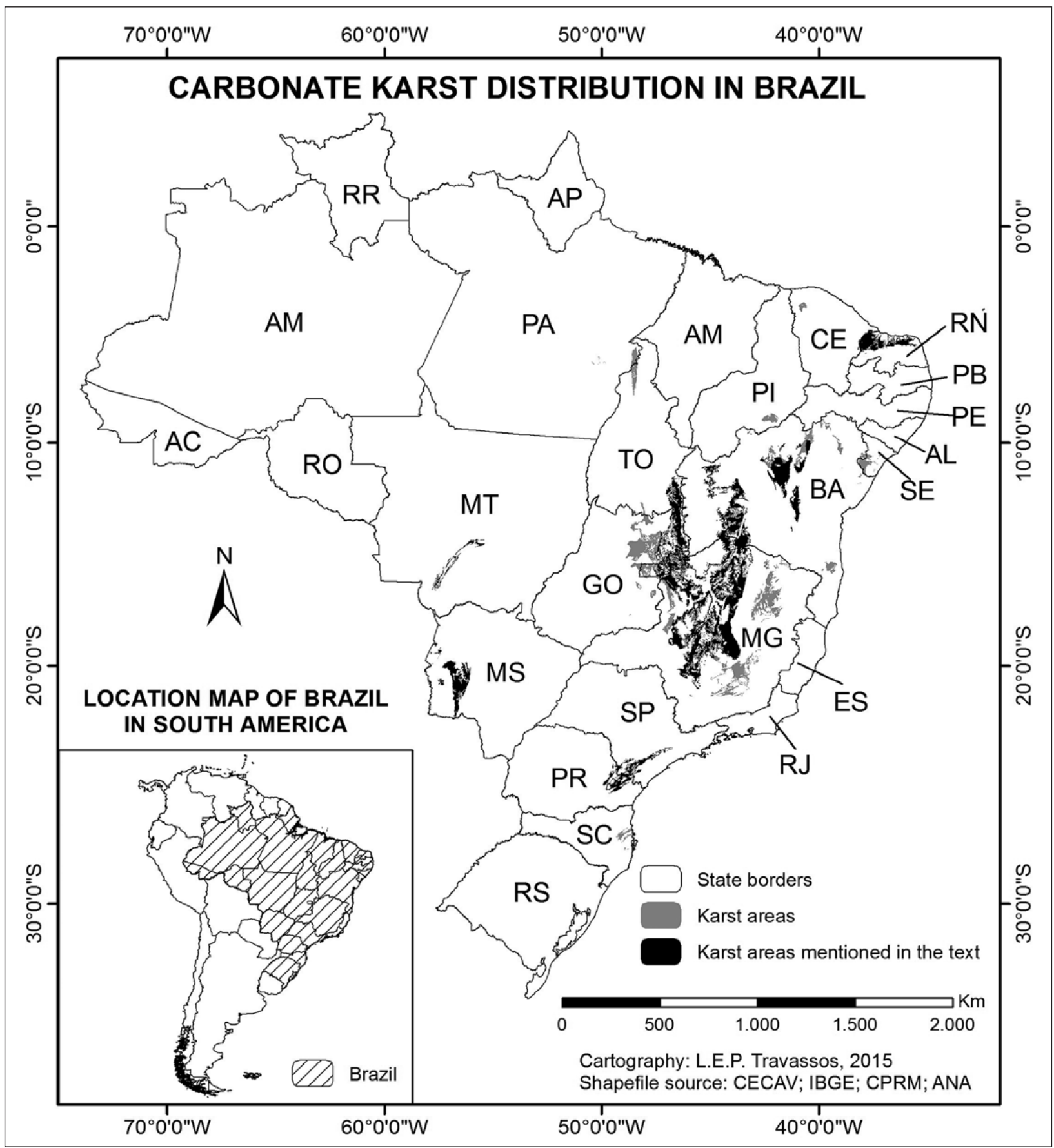

Fig. 3: Location map of Brazilian karst areas with highlight to the areas mentioned in this paper. 
(2011) also identified tufa deposits. The Araras Ridge tufa extends for over $30 \mathrm{~km}$ along a $100 \mathrm{~m}$ high fault scarp. The deposit comprises massive crystalline calcite occurring both as in situ tufa deposited along the vertical face of the scarp and as extensive debris deposits resulting from erosional disaggregation of the scarp. Sallun Filho et al. (2009a, b) highlight that Serra da Bodoquena, located in the Mato Grosso do Sul State, in the central western part of Brazil, on the southern edge of the Pantanal wetland region, is one of the most extensive continuous karst areas in this country. In that region, Quaternary tufa deposits occur widely associated with the karst system that developed on carbonate rocks of the Corumbá Group. The deposition of tufa is favored in the Serra da Bodoquena due to the predominance of autogenic waters, which allow groundwater to be enriched in calcium carbonate. The precipitation of carbonate is favored as a result of small quantities of siliciclastic sediment, which helps biological activity. Continuing to show the impor- tance of the Serra da Bodoquena, Boggiani et al. (2011) present a panorama of touristic activities in the Bodoquena Plateau, also highlighting the widespread active limestone tufas which could be one of the features that would help the creation of a geopark.

In the State of São Paulo, in the southeast of Brazil, Almeida et al. (2011) and Sallun Filho et al. (2012) show active and ancient tufa deposits that occur along drainage channels in the Serra do André Lopes region. They are associated to a karst system developed on dolomites and a super humid subtropical climate. As in other cases mentioned here, the predominance of autogenic waters enables groundwater to become enriched with calcium carbonate, with low terrigenous sediment content. Almeida et al. (2011) point out that the occurrence of such deposits in the Serra do André Lopes region had already been mentioned in geological maps in the 1980s.

\section{NOTES ON THE TUFAS OF MONTES CLAROS, MINAS GERAIS}

The study area is limited by the Mel Ridge, locally called Ibituruna Ridge, which is located in the southwest of the city of Montes Claros. The ridge is part of the Residual
Plateau of the São Francisco River and altitudes can reach 1,000 meters in some places. One of the sources of the Vieira River is located approximately at $750 \mathrm{~m}$ a.s.l. and,

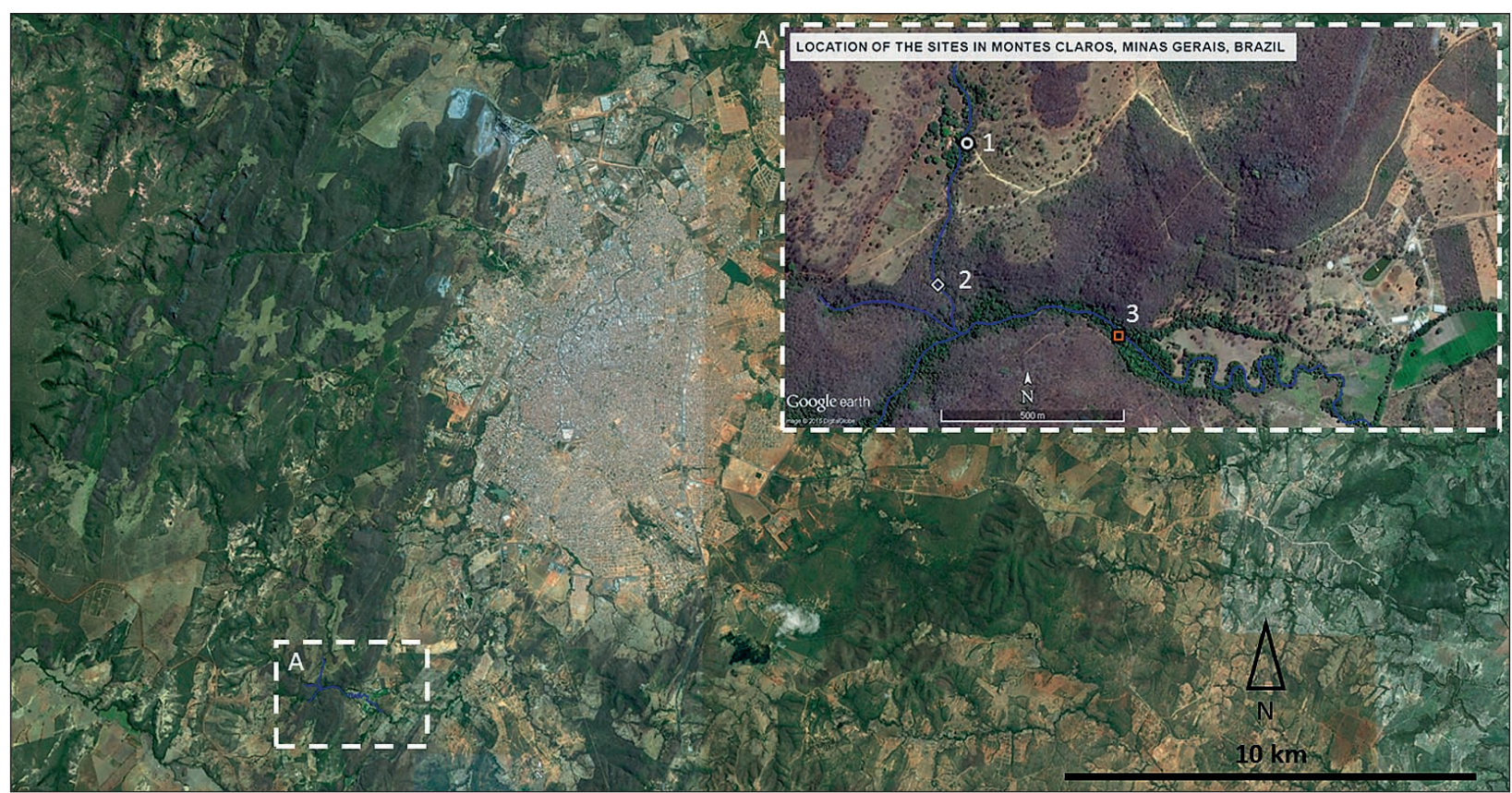

Fig. 4: Google image showing the location of the features described in the text. The larger image shows the location of the study area (A) in relation to the city of Montes Claros, midle sized city with approximately 362,000 inhabitants. The details identify 1 - Entrance of the

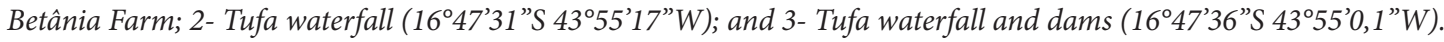



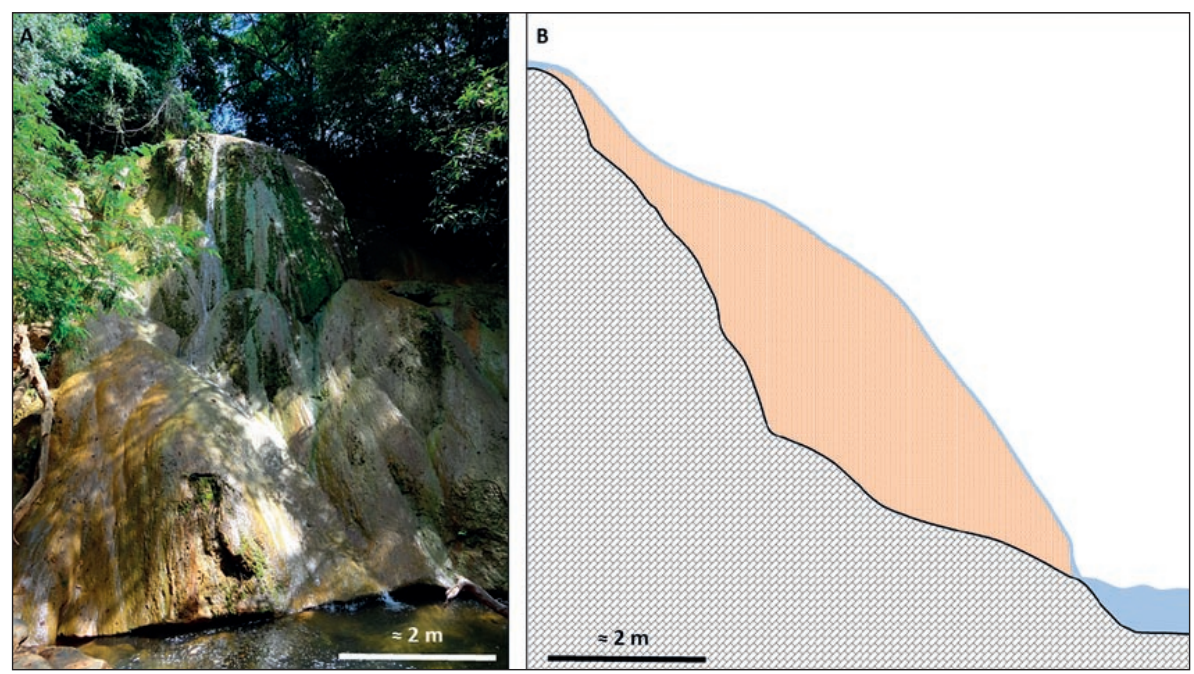

Fig. 5: General overview of the tufa waterfall (Photos: L.E.P. Travassos). due to the rough characteristics of the terrain, erosion can act strongly during pluvial events. The drainage is typically karstic and presents some seasonality. The recording of the tufa deposits of Montes Claros were made "by chance", during a field trip with students from the Graduate Program in Geography, PUC Minas University. The features that were then identified for the first time are pointed out in Fig. 4.

Moving south from the Betânia Farm (1), in a wellmarked trail, it is possible to reach the first tufa deposit (2). It is formed by the waters of the Palmital creek, tributary of the Vieira River. This deposit is approximately 8 meters high and it is possible to identify the association with organic matter (Fig. 5). As mentioned by Carthew et al. (2003) and Sallum Filho et al. (2012), one can affirm that vegetation in tropical systems are also important in order to control the morphology of tufa deposits. The relatively high declivity may help the loss of $\mathrm{CO}_{2}$ due to water turbulence and the flow of water directly on carbonate rocks.

In the waterfall, one can see debris from fallen trees as well as leaves between layers of deposition. The leaves and other organic matter are supplied by the Dry Forest, which can lose much of its cover during the dry
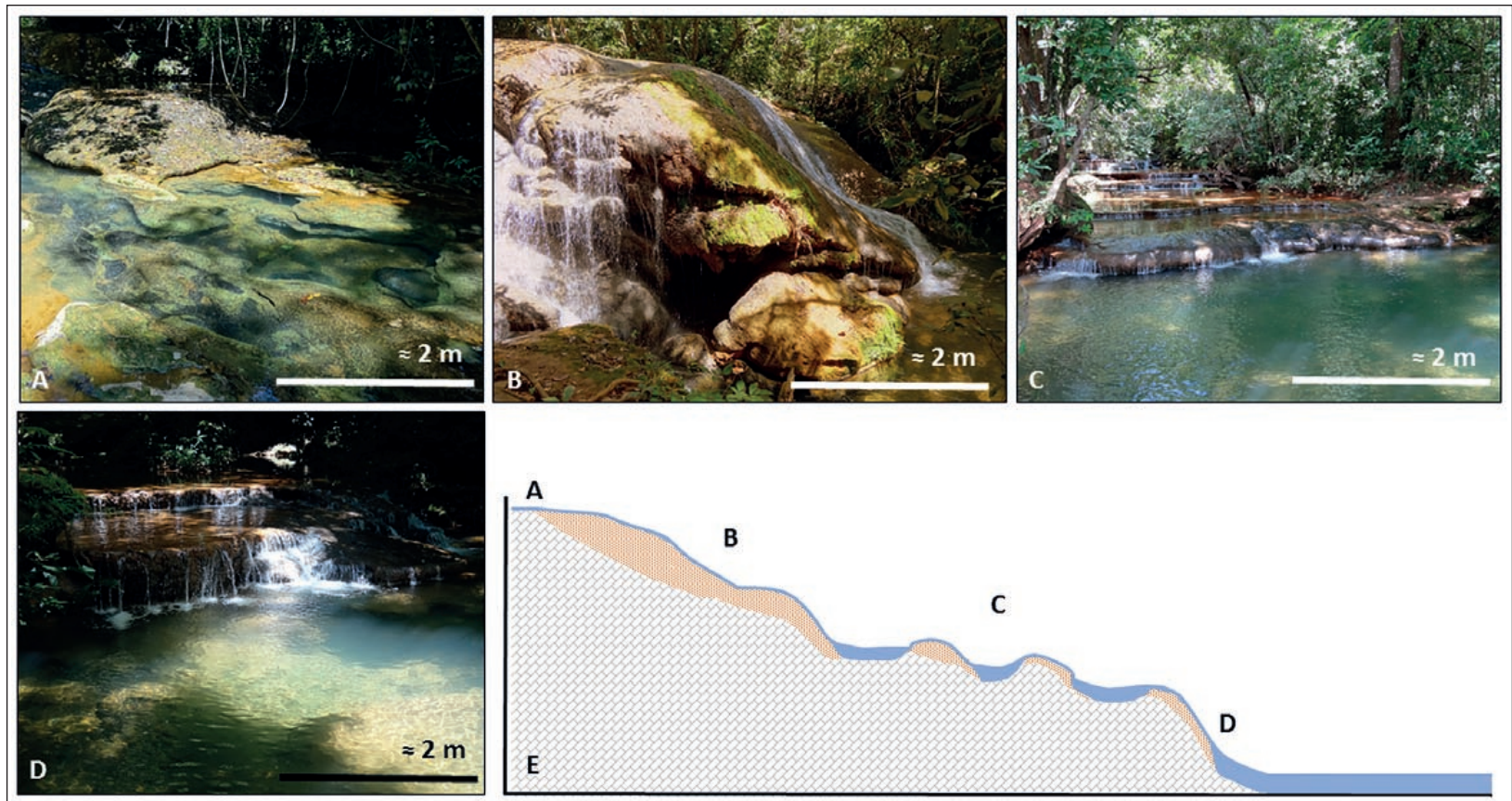

Fig. 6: General overview and inferred cross section of the Vieira River with tufa waterfall and dams. On (E) it is possible to observe a conceptual model location of each feature shown by the pictures (Photos: L.E.P. Travassos). 
season. The authors were able to observe that this deposit was formed directly over the carbonates from the Lagoa do Jacaré Formation, although sediments supplied by the non-carbonate rocks or by the pedological cover may be found in between its deposition layers. In the area, one can observe that the karst system recharge is mainly autogenic and this may explain the presence of such tufas.

Continuing downstream, one can reach the Vieira River, where there is active tufa deposition in the form of small waterfalls and dams (Fig. 6). These deposits are formed by clear waters, probably with low concentrations of sediments, as suggested by Arenas et al. (2000) and Sallum Filho et al. (2012). The presence of tufas in the area indicates specific environmental, geomorphological and hydrological conditions such as high concen- trations of calcium carbonate dissolved in the water and a favorable climate. According to Gradziński (2010), the biological activity is also important for the development of tufas.

As in the first identified example, water flowing on carbonate can have an important role in formation of the typical waterfalls, dams and pools. One can see dense vegetation along the river valley, which supports the statement of Carthew et al. (2003). Woody debris in the riverbed, fallen trees and exposed roots along the channel play a noteworthy role in tufa deposition by locally increasing stream turbulence and $\mathrm{CO}_{2}$ outgassing. In the study area, the Dry Forest and the soil cover can create favorable conditions (e.g. accumulation of plant material and sediments) for the initial growth of waterfalls or dams.

\section{CONCLUSIONS}

The Montes Claros karst region lies in the northern area of Minas Gerais State and was developed in the Proterozoic carbonates of the Bambuí Group. This region is located in the São Francisco Craton, part of a complex geological history. The karst features in the study area is located approximately $8 \mathrm{~km}$ southwest of the city of Montes Claros and can be considered endangered regarding the pressures originated from uncontrolled leisure activities. During the field trip it was possible to identify waste disposal near the riverbeds and natural gully erosion enlarged by motocrossing practice. The increase of weathering in the carbonate rocks as well as the increase of sediments in water can lead to the abrasion of tufa deposits development.

For future works (of the authors or others interested in the topic), it is suggested that some measurements of temperature, $\mathrm{pH}$, conductivity and the analyses of carbonate, magnesium, phosphate and nitrate quantities in the water from the springs and along the river be done since such information should help understand the main processes occurring in the area. Although tufa precipitation is usually due to degassing of $\mathrm{CO}_{2}$ (which elevates $\mathrm{pH}$ and produces supersaturation), mineral precipitation is also heavily influenced by biotic activity which it is believed to be high in the region. The authors also encourage isotopic studies to help better understand the paleoclimate of the region.

One can expect to find other deposits in the rivers of the region that must be registered and studied in order to help preserving them.

\section{REFERENCES}

Alkmim, F.F., Brito Neves, B.D., \& J.C. Alves, 1993: Arcabouço tectônico do Cráton do São Francisco uma revisão.- O Cráton do São Francisco, 1, 45-62.

Alkmim, F.F., Chemale Jr, F., \& I. Endo, 1996: A deformação das coberturas proterozóicas do Cráton do São Francisco e seu significado tectônico.- Revista da escola de Minas, 49, 22-38.
Alkmim, F.F. \& M.A. Martins-Neto, 2001: A bacia intracratônica do São Francisco: Arcabouço estrutural e cenários evolutivos.- In: Paiva Pinto, C. \& M. A. Martins-Neto (eds.) Bacia do São Francisco: geologia e recursos naturais. SBG/MG, pp. 9-30, Belo Horizonte. 
Almeida, F.D., 1981: O Cráton do Paramirim e suas relações com o do São Francisco.- In: Proceedings of the Simpósio sobre o Cráton do São Francisco e suas Faixas marginais, 1981, Salvador, Bahia. SBG/BA, $1-10$, Salvador.

Almeida, F.D., 1977: O cráton do São Francisco.- Revista Brasileira de Geociências, 7, 349-364.

Almeida, F.F.M., 1967: Origem e evolução da plataforma brasileira.- DNPM/DGM, pp. 1-36, Rio de Janeiro.

Almeida, L.H.S., Sallum Filho, W., Karman, I. \& P.C. Boggiani, 2011: Quaternary tufas in the Serra do André Lopes, southeastern Brazil.- Rend. Online Soc. Geol. It., 16, 5-6.

Andrews, J.E., 2006: Palaeoclimatic records from stable isotopes in riverine tufas-synthesis and review.Earth-Science Reviews, 75, 85-104. http://dx.doi. org/10.1016/j.earscirev.2005.08.002

Andreychouk, V., Travassos, L.E.P. \& E.P. Barbosa, 2010: As cavernas como objetos do turismo religioso em diferentes crenças religiosas: alguns exemplos mundiais.- O Carste, 22, 48-64.

Antonino, L.Z., \& L.E.P. Travassos, 2012: Geossímbolos e as comunidades quilombolas de Ouro Verde de Minas, Minas Gerais, Brasil.- In: Proceedings of the IV Congresso Argentino y I Latino Americano de Espeleología, 2012, Malargüe, Mendoza. Federación Argentina de Espeleología, 31-32, Malergüe.

Arenas, C., Gutiérrez, F., Osácar, C. \& C. Sancho, 2000: Sedimentology and geochemistry of fluvio-lacustrine tufa deposits controlled by evaporite solution subsidence in the central Ebro Depression, NE Spain.- Sedimentology, 47, 883-909. http://dx.doi. org/10.1046/j.1365-3091.2000.00329.x

Auler, A.S. \& P.L. Smart, 2001: Late Quaternary paleoclimate in semiarid northeastern Brazil from U-series dating of travertine and water table speleothems.Quat. Res., 55, 159-167. http://dx.doi.org/10.1006/ qres.2000.2213

Baptista, M.C., 2004: Estratigrafia e Evolução Geológica da Região de Lagoa Formosa (MG).- Masters Degree thesis. Federal University of Minas Gerais, pp. 104.

Barbosa, O., 1965: Série Bambuí.- In: Proceedings of the $19^{\text {th }}$ Brazilian Congress of Geology, 1965, Rio de Janeiro. SBG/RJ, 15, Rio de Janeiro.

Boggiani, P.C. \& A.M. Coimbra, 1995: Quaternary limestones of the Pantanal Area, Brazil.- Anais da Academia Brasileira de Ciências, 67, 343-349.
Boggiani, P.C., Coimbra, A.M., Gesicki, A.L., Sial, A.N., Ferreira, V.P., Ribeiro, F.B. \& J.M. Flexor, 2002: Tufas Calcárias da Serra da Bodoquena: cachoeiras petrificadas ao longo dos rios.- In: Schobbenhaus, C., Campos, D.A., Queiroz, E.T., Winge, M. \& M. Berbert-Born (eds.) Sítios Geológicos e Paleontológicos do Brasil. DNPM/CPRM/SIGEP, pp. 249-259, Brasília.

Boggiani, P.C., Coimbra, A.M., Gesicki, A.L., Sial, A.N., Ferreira, V.P., Ribeiro, F.B. \& J. M. Flexor, 1999: Tufas Calcárias da Serra da Bodoquena.- In: Schobbenhaus, C., Campos, D.A., Queiroz, E.T., Winge, M. \& M. Berbert-Born (eds.) Sítios Geológicos e Paleontológicos do Brasil. DNPM/CPRM/SIGEP, pp. 1-16, Brasília.

Boggiani, P. C., Coimbra, A. M., Ribeiro, F., Flexor, J., Sial, A. N., \& Ferreira, V. P., 1998: Significado paleoclimático das Lentes Calcárias do Pantanal do Miranda: Mato Grosso do Sul.- In: Proceedings of the 40 Brazilian Geological Congress, 1998, Belo Horizonte. SBG/MG, 88, Belo Horizonte.

Boggiani, P.C., Trevelin, A.C., Sallun Filho, W., Oliveira, E.C. de \& L.H.S. Almeida, 2011: Turismo e conservação de tufas ativas da Serra da Bodoquena, Mato Grosso do Sul.- Tourism and Karst areas, 4, 55-63.

Borges, F. de A.C., Travassos, L.E.P. \& F.A. Guimarães, 2013: Proposal to establish geotouristic trails at the Monumento Natural Estadual Gruta Rei do Mato, Sete Lagoas, Minas Gerais.- In: Proceedings of the $16^{\text {th }}$ International Congress of Speleology, 2013, Brno. Czech Speleological Society/SPELEO2013/UIS, 209-214, Brno.

Branner, J.C., 1911: Aggraded limestone plains of the interior of Bahia and the climatic changes suggested by them.-Geological Society of America Bulletin, 22, 187-206.

Braun, O.P.G., 1968: Contribuição à estratigrafia do Grupo Bambuí. In: Proceedings of the XXII Brazilian Geological Congress, 1968, Belo Horizonte. SBG/ MG, 219-222, Belo Horizonte.

Capezzuoli, E., Gandin, A. \& M. Pedley, 2014: Decoding tufa and travertine (fresh water carbonates) in the sedimentary record: The state of the art.- Sedimentology, 61, 1-21. http://dx.doi.org/10.1111/ sed. 12075

Carthew, K.D., Taylor, M.P. \& R.N. Drysdale, 2003: Are current models of tufa sedimentary environments applicable to tropical systems? A case study from the Gregory River.- Sediment Geol., 62, 199-218. http://dx.doi.org/10.1016/S0037-0738(03)00151-9 
Carvalho, R.T. \& R. Pflug, 1968: Observações sobre a estratigrafia da Serie Minas na região de Diamantina, MG.- DGM/DNPM, pp.20, Rio de Janeiro.

Chaves, M.L. de S.C., Andrade, K.W., Benitez, L., 2011: Geologia integrada das Folhas Jequitaí, Bocaiúva e Montes Claros (1:100.000), norte de Minas Gerais.Geonomos, 19, 1-7.

Coelho, J.C.C., 2007: Estilos estruturais e evolução tectônica de borda oeste da Bacia do São Francisco, com base na integração de dados de superfície e sub-superfície, litogeoquímica e isótopos.- Masters Degree thesis. Federal University of Ouro Preto, pp. 115.

Corrêa, D., Auler, A.S., Wang, X., Edwards, R.L., \& H. Cheng, 2011: Geomorphology and genesis of the remarkable Araras Ridge tufa deposit, Western Brazil.- Geomorphology, 134, 94-101. http://dx.doi. org/10.1016/j.geomorph.2011.06.034

Corrêa, D. 2006: Caracterização, cronologia e gênese das tufas da Serra das Araras-Mato Grosso.- Masters Degree thesis. Federal University of Minas Gerais, pp. 80.

Dardenne, M.A., 1978: Síntese sobre a estratigrafia do Grupo Bambuí no Brasil Central.- In: Proceedings of the 30 ${ }^{\text {th }}$ Brazilian Geological Congress, 1978, Recife. SBG/PE, 597-610, Recife.

Diniz, A.M., Travassos, L.E.P., Brandão, V.S. \& F.V.P. Rios, 2013: Some aspects of the geographical distribution of Buddhist caves. In: Proceedings of the 16th International Congress of Speleology, 2013, Brno. Czech Speleological Society/SPELEO2013/UIS, 365-368, Brno.

Duarte, L. \& M.E.C. Vasconcelos, 1980a: Vegetais do Quaternário do Brasil. I- Flórula de Russas, CE.Anais da Academia Brasileira de Ciências, 52, 37-48.

Duarte, L. \& M.E.C. Vasconcelos, 1980b: Vegetais do Quaternário do Brasil. I-Flórula de Umbuzeiro, PB, CE.- Anais da Academia Brasileira de Ciências, 52, 93-180.

Evangelista, V.K. \& L.E.P. Travassos, 2014: Patrimônio Geomorfológico do Parque Estadual do Sumidouro.PUC Minas, pp. 140, Belo Horizonte.

Ford, T.D., \& H.M. Pedley, 1996: A review of tufa and travertine deposits of the world.- Earth-Science Reviews, 41, 117-175. http://dx.doi.org/10.1016/ S0012-8252(96)00030-X

Gradziński, M., 2010: Factors controlling growth of modern tufa: results of a field experiment.- In: Pedley, H.M. \& M. Rogerson (eds). Tufas and speleothems: unravelling the microbial and physical controls. Geological Society of London, pp. 143-191, London.
Guimarães, R.L. \& L.E.P. Travassos, 2011: Geomorphological mapping of the Monjolos Karst Region, Minas Gerais, Brazil. In: Proceedings of the $19^{\text {th }}$ International Karstological Schoool Classical Karst - Underground Protection, 2011, Postojna. Karst Research Institute/ Scientific Research Centre of the Slovenian Academy of Sciences and Arts, 42, Postojna.

Iglesias, M. \& A. Uhlein, 2009: Estratigrafia do Grupo Bambuí e coberturas fanerozóicas no vale do rio São Francisco, norte de Minas Gerais.- Revista Brasileira de Geociências, 39, 256-266.

Jones, B., \& R.W. Renaut, 2010: Calcareous spring deposits in continental settings.- In: Alonso-Zarza, A.M., \& L.H. Tanner (eds). Carbonates in continental settings: facies, environments, and processes. Elsevier, pp. 177-224, Amsterdam.

Lobo, H.A. S. \& L.E.P. Travassos, 2012: O ser humano e a paisagem cárstica / Humans and karst landscape.- Sociedade Brasileira de Espeleologia, pp. 92, Campinas.

Lobo, H.A.S. \& L.E.P. Travassos, 2013: Cave tourism in Brazil: General aspects and trends from the beginning of the $21^{\text {st }}$ century.- Journal of the Australasian Cave and Karst Management Association, 93, 6-14.

Martins-Neto, M.A. \& F.F. Alkmim, 2001: Estratigrafia e evolução tectônica das bacias neoproterozóicas do paleocontinente São Francisco e suas margens: Registro da quebra de Rodínia e colagem de Gondwana.- In: Pinto, C.P. \& M.A. Martins-Neto (eds.). Bacia do São Francisco: Geologia e Recursos Naturais. SBG/MG, pp. 31-54, Belo Horizonte.

Moutinho da Costa, L.A., Angeiras, A.G., Valença, J.G., \& V. Stevenazzi, 1970: Novos conceitos sobre o Grupo Bambuí e sua divisão em tectonogrupos.- Boletim Geologia. Instituto de Geociências, 5, 3-34.

Oliveira, M. A. M. de, 1967: Contribuição à geologia da parte sul da Bacia do são Francisco e áreas adjacentes.- Coletâneas de Relatórios de Exploração, 1, 71-105.

Pedley, H.M., 1990: Classification and environmental models of cool freshwater tufas.- Sedimentary Geology, 68, 143-154. http://dx.doi.org/10.1016/00370738(90)90124-C

Pentecost, A., 2010: Preservation of Natural and Historic Heritage Sites.- In: Alonso-Zarza, A.M., \& L.H. Tanner (eds) Carbonates in continental settings: facies, environments, and processes. Elsevier, pp. 297-311, Amsterdam.

Pentecost, A., 2005: Travertine.- Springer-Verlag, pp. 445, Berlin. 
Pentecost, A., 1995: The quaternary travertine deposits of Europe and Asia Minor.- Quaternary Science Reviews, 14, 1005-1028. http://dx.doi. org/10.1016/0277-3791(95)00101-8

Pflug, R \& F.E. Renger, 1973: Estratigrafia e evolução geológica da margem SE do Cráton do São Francisco.In: Proceedings of the $27^{\text {th }}$ Brazilian Geological Congress, 1973, Aracaju. SBG/SE, 5-9, Aracaju.

Pôssas, I.B., Travassos, L.E.P. \& B.D. Rodrigues, 2012: Registros de Peter W. Lund sobre a região de Lagoa Santa, Minas Gerais: possibilidades para o turismo pedagógico e científico.- Pesquisas em Turismo e Paisagens Cársticas, 5, 25-33.

Rodrigues, B.D. \& L.E.P. Travassos, 2013: Identificação e mapeamento das Matas Secas associadas ao carste carbonático de Santo Hipólito e Monjolos, Minas Gerais.- Mercator (UFC), 12, 233-256. http:// dx.doi.org/10.4215/RM2013.1229. 0015

Sallun Filho, W., 2012: Paleoclimatic records of Quaternary tufa in the Serra do André Lopes karst, southeastern Brazil.- Quaternary International, 279, 423-424. http://dx.doi.org/10.1016/j. quaint.2012.08.1367

Sallun Filho, W., Almeida, L.H.S., Boggiani, P.C., \& I. Karmann, 2012: Characterization of quaternary tufas in the Serra do André Lopes karst, southeastern Brazil.- Carbonates and evaporites, 27, 357-373. http://dx.doi.org/10.1007/s13146-012-0118-1

Sallun Filho, W., Karmann, I., Sallun, A.E.M., \& K. Suguio, 2009a: Quaternary tufa in the Serra da Bodoquena karst, west-central Brazil: Evidence of wet period.- IOP Conference Series: Earth and Environmental Science, 6, 072055. http://dx.doi. org/10.1088/1755-1307/6/7/072055

Sallun Filho, W., Karmann, I., Boggiani, P.C., Petri, S., Cristalli, P.D.S., \& G. Utida, 2009b: A deposição de tufas quaternárias no estado de Mato Grosso do Sul: proposta de definição da formação Serra da Bodoquena.- Geologia USP, 9, 47-60.

Schobbenhaus, C. \& B.B. de Brito Neves, 2003: A geologia do Brasil no contexto da plataforma sul-americana.- In: Bizzi, L.A., Schobbenhaus, C., Vidotti, R.M. \& J.H. Gonçalves (eds.) Geologia, Tectônica e recursos minerais do Brasil: Textos, mapas e SIG.CPRM, pp. 5-54, Brasília.

Scholl, W.U., 1972: Der Sudwestliche randbereich der Espinhaço Zone, Minas Gerais, Brasilien.- Geol. Rdsch., 61, 201-216. http://dx.doi.org/10.1007/ BF01836139

Timo, M.B., 2015: O Carste da Região de Córrego do Cavalo, Piumhi, Minas Gerais, Brasil.- Novas Edições Acadêmicas, pp. 153, Saarbrücken.
Timo, M.B., Travassos, L.E.P. \& B.D. Rodrigues, 2012: Proposta de delimitação da Unidade Geomorfológica Província Cárstica Arcos-Pains-Doresópolis.- In: X Seminário Cláudio Peres, 2012, Belo Horizonte. PUC Minas, Belo Horizonte.

Timo, M.B., Travassos, L.E.P. \& B.D. Rodrigues, 2013: Pre-historic remains at the Corrego of Cavalo Farm, Piumhi, Minas Gerais, Brazil. In: Proceedings of the 16th International Congress of Speleology, 2013, Brno. Czech Speleological Society/SPELEO2013 / UIS, 196-201, Brno.

Travassos, E.P.L. \& H.C. Kohler, 2009: Historical and geomorphological characterization of a Brazilian karst region.- Acta Carsologica, 38, 2/3, 277-291. http://dx.doi.org/10.3986/ac.v38i2-3.128

Travassos, L.E.P., 2010: Considerações sobre o carste da região de Cordisburgo, Minas Gerais, Brasil.Tradição Planalto, pp. 102, Belo Horizonte.

Travassos, L.E.P., 2012: The cultural importance of karst and caves: from ancient times to the present.- Lambert Academic Publishing, pp. 316, Saarbrücken.

Travassos, L.E.P., Magalhães, E.D. \& E.P. Barbosa, 2011: Cavernas, rituais e religião.- Editus, pp. 441, Ilhéus.

Travassos, L.E.P., Pôssas, I.B. \& B.D. Rodrigues, 2012: Projeto Memória da Geomorfologia Cárstica Mineira: Prof. Dr. Heinz Charles Kohler.- Tradição Planalto, 1 DVD, Belo Horizonte.

Travassos, L.E.P., Rodrigues, B.D. \& M.B. Timo, 2015: Glossário conciso e ilustrado de termos cársticos e espeleológicos.- PUC Minas, pp. 65, Belo Horizonte.

Travassos, L.E.P., Travassos, E.G., Travassos, L.P. \& L.C.P. Travassos, 2007: Non-specialists perception about endokarst and exokarst scenarios: visions from high school students.- Acta Carsologica, 36, 329-335. http://dx.doi.org/10.3986/ac.v36i2.202

Valadão, R.C., 1998: Evolução de Longo-Termo do Relevo do Brasil Oriental (Desnudação, Superfícies de Aplanamento e Soerguimentos Crustais). PhD dissertation, Federal University of Bahia, pp.243.

Viles, H.A. \& A. Pentecost, A., 2007: Tufa and travertine.In: Nash, D.J. \& S. McLaren (Eds) Geochemical Sediments and Landscapes. Blackwell Publications, pp. 173-199, Oxford.

Wang, X., Auler, A.S., Edwards, R.L., Cheng, H., Cristalli, P.S., Smart, P.L, Richards, D.A. \& C. Shen, 2004: Wet periods in northeastern Brazil over the past $210 \mathrm{kyr}$ linked to distant climate anomalies.- Nature, 432, 740-743. 